\title{
Metabolic syndrome and renal cell carcinoma
}

\author{
Gui-Ming Zhang ${ }^{1,2}$, Yao Zhu ${ }^{1,2}$ and Ding-Wei Ye 1* $^{*}$
}

\begin{abstract}
Background: Metabolic syndrome (MS) is a cluster of metabolic abnormalities, which has been regarded as a pivotal risk factor for cardiovascular diseases. Recent studies focusing on the relationship between MS and cancer have recognized the significant role of MS on carcinogenesis. Likewise, growing evidence suggests that MS has a strong association with increased renal cell carcinoma (RCC) risk. This review outlines the link between MS and RCC, and some underlying mechanisms responsible for MS-associated RCC.

Materials and methods: A National Center for Biotechnology Information PubMed search (www.pubmed.gov) was conducted using medical subject headings 'metabolic syndrome', 'obesity', 'hypertension', 'diabetes', 'dyslipidemia', and 'renal cell carcinoma'.

Results: This revealed that a variety of molecular mechanisms secondary to MS are involved in RCC formation, progression, and metastasis. A deeper understanding of these molecular mechanisms may provide some strategies for the prevention and treatment of RCC.

Conclusions: In summary, there is a large body of evidence regarding the link between MS and RCC, within which each component of MS is considered to have a close causal association with RCC.
\end{abstract}

Keywords: Metabolic syndrome, Renal cell carcinoma, Insulin resistance, Mechanism

\section{Review}

\section{Background}

Metabolic syndrome (MS) has become an almost ubiquitous severe health issue across the globe. It is estimated that more than $40 \%$ U.S. residents over the age of 60 years have MS [1], with a prevalence of approximately $25 \%$ in European and Latin populations [2,3]. Over recent decades there has been an alteration of dietary pattern and lifestyle in Chinese people, and subsequently an elevated morbidity associated with MS year by year. According to an analysis of data in 2005, up to $20 \%$ Chinese adults suffered from MS [4]. The concern regarding MS was primarily focused on its contribution to increased cardiovascular disease and type 2 diabetes mellitus risk. Recently, the relationship between MS and cancer has been highlighted by the observation that MS is associated with high morbidity and mortality for certain types of cancer. This review summarizes evidence in support of the relationship between MS and renal cell

\footnotetext{
*Correspondence: dwyeli@163.com

'Department of Urology, Fudan University Shanghai Cancer Center, No. 270, Dongan Rd, Shanghai 200032, China

Full list of author information is available at the end of the article
}

carcinoma (RCC) and possible underlying mechanisms and therapeutic interventions.

\section{Definition of metabolic syndrome}

MS was first described using the term 'syndrome $X$ ' by Reaven in 1988 [5], with insulin resistance (IR) as the common and elementary denominator. It comprises a cluster of metabolic abnormalities, each of which is an important atherosclerotic risk factor. With a deeper understanding of MS, more sophisticated mechanisms have been revealed, and IR is recognized as one of the most significant factors. Because IR is not easily measured clinically, it is not included in all of the definitions developed by different organizations, whereas abdominal obesity, dyslipidemia, hypertension, and impaired glucose regulation have been adopted in almost all of the diagnostic criteria. For example, NCEP/ATP III (National Cholesterol Education Program/Adult Treatment Panel III) sets three of five of the following criteria as necessary for a diagnosis of MS: fasting glucose $\geq 110 \mathrm{mg} / \mathrm{dl}$; hypertriglyceridemia $\geq 150 \mathrm{mg} / \mathrm{dl}$; low high-density-lipoprotein (HDL) levels - male $<40 \mathrm{mg} / \mathrm{dl}$, female $<50 \mathrm{mg} / \mathrm{dl}$; abdominal obesity - male $>102 \mathrm{~cm}$, female $>88 \mathrm{~cm}$ waist circumference; hypertension, $\geq 130 / \geq 85 \mathrm{mmHg}$. In 1998, the 
World Health Organization (WHO) recommended a unifying definition and revised this in the following year: impaired glucose regulation and/or hyperinsulinemia (fasting glucose $\geq 110 \mathrm{mg} / \mathrm{dl}$; post-prandial glucose $>140 \mathrm{mg} / \mathrm{dl}$; fasting serum insulin: third quartile for control group) and two or more criteria are necessary: (1) hypertension, $\geq 140 / \geq 90 \mathrm{mmHg}$; (2) hypertriglyceridemia, $\geq 150 \mathrm{mg} / \mathrm{dl}$; low HDL levels - male $<35 \mathrm{mg} / \mathrm{dl}$, female $<39 \mathrm{mg} / \mathrm{dl}$; (3) abdominal obesity - waist:hip ratio, male $>0.90$, female $>0.85$, and/or body mass index (BMI) $\geq 30 \mathrm{~kg} / \mathrm{m}^{2}$; (4) microalbuminuria, $\geq 20 \mu \mathrm{g} / \mathrm{min}$.

\section{MS and cancer}

There is increasing evidence to indicate that MS might play an important role in the etiology and progression of certain types of cancers. The association of MS with liver, pancreatic, gastric, colorectal, bladder, prostate, endometrial, cervical, and postmenopausal breast cancers have all been reported [6-14]. A systematic review published in 2012 showed that MS was associated with pancreatic and rectal cancer, and these associations were stronger in women than in men. Additionally, associations were different for ethnic groups: stronger associations were observed in Asian populations for liver cancer, in European female populations for colorectal cancer and in U.S. Caucasian populations for prostate cancer [15]. Cancer patients with concomitant MS seem to have a worse prognosis. Buschemeyer et al. reported that obese patients with prostate cancer were more likely to suffer from high-grade and aggressive cancer [16]. Compared with those with high cholesterol levels, men with normal or borderline levels were less likely to develop high-grade prostate cancer, particularly when considering cases in which the cancer was confined to the pancreas [17]. A conclusion that MS is a risk factor for lethal prostate cancer has also been reported [11]. Further, the rates of liver metastasis and tumor recurrence were higher in patients with colorectal cancer accompanied by MS [18], and Pasanisi et al. observed a higher recurrence rate in breast cancer patients with concomitant MS [19].

\section{MS and renal cell carcinoma}

Renal cell carcinoma (RCC), a common type of urologic tumor, accounts for $2 \%$ to $3 \%$ of all malignancies. According to data provided by the WHO, the morbidities of RCC appear to be showing an upward trend in recent years in a range of regions and ethnicities, except for in Scandinavia [20]. Although the etiology of RCC remains unclear, previous research has identified smoking and diet as risk factors. Moreover, data from a large set of studies suggest a significant association between RCC and the major components of MS, among which obesity and hypertension have been listed as confirmed etiological factors in the guidelines by many organizations, for example, the European Association of Urology, the American Urological Association, and the Chinese Urological Association.

\section{Obesity and RCC}

Accumulating evidence indicates that, as an independent risk factor, obesity is significantly associated with RCC [21]. A study whose conclusion was published in the British Journal of Cancer analyzed 22 independent clinical studies available in MEDLINE from 1966 to 1998. By means of quantitative summary analysis, the authors reported that the link between MS and RCC was stronger among men with higher BMI, and the relative risk for men and women together was 1.07 (95\% CI: 1.051.09) per unit of increase in BMI (one unit of increase in BMI corresponds to $3.1 \mathrm{~kg}$ for a man of an average height of $1.77 \mathrm{~m}$, and to $2.7 \mathrm{~kg}$ for a woman of an average height of $1.64 \mathrm{~m}$ ) [22]. Leiba and his colleagues conducted a study comprising 19,576,635 person-years of follow-up and drew a conclusion that being overweight in late adolescence was a substantial risk factor for RCC, and European origin was independently associated with excess risk compared with Asian or African origin [23]. Nevertheless, it is of interest that obesity seems to be a favorable factor in terms of prognosis of RCC, despite its contribution to increased RCC risk. For patients with organ-confined but not advanced RCC, being overweight improved their cancer specific survival [24]. Another study also reported that cancer-specific survival time, but not overall survival time, was notably prolonged for patients with increasing BMI $\left(>30 \mathrm{~kg} / \mathrm{m}^{2}\right)$ who had received radical nephrectomy [25].

Some recently published studies showed that compared with subcutaneous adipose tissue, visceral adipose tissue seemed more harmful to health, and to be a better indicator than BMI of obesity. In addition to the traditional measure of waist:hip ratio, visceral fat area (VFA) measured using imaging methods has become a new research 'hotspot'. Zhu et al. investigated the relationship between tumor grade and VFA in patients with RCC of stage T1a and found that the percentage of visceral adipose tissue was significantly associated with higher Fuhrman grade and might be an independent predictor of high grade RCC [26]. However, visceral adipose tissue is likely to play a protective role in advanced RCC patients who are receiving first-line targeted therapy, such as sorafenib and sunitinib. The fact that those patients with higher levels of VFA had a longer progression-free survival time and OS has been reported in a retrospective study [27]. The reason why obesity is associated with increased RCC risk but improved prognosis is not yet well understood. It has been speculated that the development of cachexia might be suppressed by obesity. Further 
studies are needed to discover the underlying biological mechanism.

\section{Hypertension and RCC}

The conclusion that hypertension can increase the risk of RCC has been confirmed by a large set of clinical studies. A study group evaluated the relationship between hypertension and RCC by examining the health records of 363,992 Swedish men, with subsequent followup studies. After the first 5 years of follow-up had been excluded to reduce possible effects of preclinical disease, the researchers still found a direct association between higher blood pressure and a higher risk of RCC [21]. Colt et al. also performed a clinical study in the U.S. and found hypertension doubled RCC risk, with OR of 1.9 (CI: 1.5-2.4) for Caucasians, and 2.8 (CI: 2.1-3.8) for African-Americans [28]. A similar conclusion was also reported in a Chinese population-based study [29]. Subtle changes of renal function prior to clinical hypertension may make the kidney more susceptible to carcinogenesis, and some angiogenic and other growth factors that are involved in hypertension may also participate in renal carcinogenesis and progression.

It is noteworthy that some interventions aiming to reduce hypertension may also increase the risk of RCC, of which diuretics merit further investigation. As the first line antihypertensive drugs that can reduce morbidity and mortality of cardiovascular disorders, diuretics are widely administrated owing to their satisfactory effect and relatively low expense. However, emerging evidence suggests that the long-term use of diuretics may be associated with RCC [30], being especially significant for women [31]. Nevertheless, because this conclusion is still controversial and the reason for it remains unclear, largescale studies to corroborate the conclusion and clarify the mechanisms are warranted.

\section{Diabetes and RCC}

The relationship between diabetes and cancer is quite close, because it is presently considered that there may exist 'common soil' responsible for both diabetes and cancer. In other words, some risk factors for diabetes likewise render people more susceptible to cancer. There are also numerous epidemiological studies focusing on the link between diabetes and RCC, showing an elevated cancer morbidity and mortality in diabetes patients. Lindblad and colleagues conducted a large scale followup study ( 1 to 25 years) in a total of 153,852 patients with a diagnosis of diabetes in Northern Europe. After exclusion of the first year of observation, they found that standardized incidence ratios (SIRs) were 1.7 (95\% CI: 1.4-2.0) in women and 1.3 (95\% CI: 1.1-1.6) in men, and standardized mortality ratios (SMRs) were 1.9 (95\% CI: 1.7-2.2) in women and 1.7 (95\% CI: 1.4-1.9) in men.
Thus, both morbidity and mortality of RCC increased in patients with diabetes in comparison with the general population [32]. Another study with a follow-up of 32 years performed in the U.S. reported type 2 diabetes was independently associated with an increased risk of RCC in women [33].

Another current research 'hotspot' concerning the impact of anti-diabetic drugs on tumor development provides indirect evidence about the role of diabetes on the etiology of cancers. Insulin can promote mitosis and cell proliferation, which results in the concern about its carcinogenic effect. However, no compelling evidence that exogenous insulin or insulin analogues may elevate cancer risks has so far been presented. Many studies have revealed the inhibitory effect of metformin on many kinds of tumor cells, including RCC cells. Metformin, one of the commonly used oral anti-diabetic drugs, is able to inhibit the growth of RCC cells in vivo and in vitro, through induction of apoptosis and G0/G1 cell cycle arrest [34,35]. No consensus as to the effect of sulfonylureas on cancer has been reached so far. Deeper and more systematic work needs to be done to clarify the relationship between anti-diabetic drugs and tumor.

\section{Dyslipidemia and RCC}

Lipid profiles include cholesterol $(\mathrm{CH})$, triglyceride (TG), and some lipoid constituents, such as phospholipids, of which $\mathrm{CH}$ and TG are clinically important. Only in the form of lipoprotein, for example, low-density-lipoprotein (LDL) and HDL, can CH and TG be transported to the tissues and be metabolically active. There are many studies validating the contribution of dyslipidemia to carcinogenesis of various cancers. An elevated risk of esophageal cancer and colon cancer was observed in people with high levels of TG [36,37], and hypercholesterolemia has been suggested as a risk factor for rectal cancer [36]. High serum $\mathrm{CH}$ and TG levels raised the risk of prostate cancer and low HDL levels were associated with breast cancer, lung cancer, and non-Hodgkin's lymphoma [38-41].

Clear cell RCC, the most common type of renal malignancy, is characterized histologically by sterol storage in tumor cells, which prompts some abnormality in lipid metabolism which plays an important role in the formation and progression of RCC. However, little research has been conducted which directly focuses on the association between RCC and lipid disorders. In a prospective cohort study, Van Hemelrijck et al. reported that TG was the only lipid component for which a statistically significant association was observed with RCC [42], whereas another prospective study reported a decreased risk of RCC associated with higher serum $\mathrm{CH}$ levels, albeit with marginal statistical significance [43]. Statins (inhibitors of 3-hydroxy-3-methylglutaryl coenzyme A reductase) that are used for the treatment of lipid disorders, especially 
hypercholesterolemia, appear to protect against the development of RCC. Horiguchi et al. reported that fluvastatin had a notable inhibitory effect in vitro on tumor growth, invasion, angiogenesis, and metastasis of RCC cells [44], which provided indirect evidence of the relationship between dyslipidemia and RCC. However, given the relative paucity of laboratory and clinical research compared with that relating to obesity, hypertension, and diabetes, further studies regarding the effect of dyslipidemia on RCC development are warranted.

\section{Mechanisms}

The mechanisms that underlie the role of MS on RCC carcinogenesis are complicated, involving insulin resistance (IR), inflammation, angiogenesis, cell-stroma interaction, and many other important aspects. A sophisticated network including various factors and signaling pathways is composed of these interrelated components, regulating the cross-talk between MS and RCC.

\section{Insulin resistance}

Hyperinsulinemia and IR are considered the primary basis of the metabolic impairment associated with MS. Insulin is one of the most important anabolic hormones that is able to stimulate cell proliferation. Harmful local and systemic reactions, including intracellular lipid accumulation in adipocytes, mitochondrial and endoplasmic reticulum stress, and IR, can be induced by obesity, accompanied by changes of circulating factors such as adipokines, free fatty acids and a variety of inflammatory mediators.

The insulin-like growth factor (IGF) family and the changes of its components resulting from IR play a crucial role in tumor formation and progression. The IGF family consists of IGF-1, IGF-2 and their receptors, IGF-1R and IGF-2R, as well as six types of IGF binding proteins (IGFBPs), IGFBP-1 to 6 . IGF-1 and IGFBP-3 are important members of the IGF family, and have been investigated in many studies to understand their role in RCC carcinogenesis. Rasmuson et al. evaluated the prognostic information of serum IGF-1 in 256 patients with RCC, and reported that IGF-1 did not correlate with tumor stage or grade, whereas tumor stage and IGF-1 levels were independent prognostic factors using a multivariable analysis. They concluded that high serum IGF-1 levels at diagnosis were related to favorable prognosis in RCC [45]. In the human RCC cell lines Caki-2 (from a primary tumor) and SK-RC-52 (from a metastasis), IGF-1 may enhance transforming growth factor- $\beta$ (TGF- $\beta$ ) signaling and raise IGFBP- 3 levels with TGF- $\beta$ acting in synergy [46]. Through activation of mitogen-activated protein kinase (MAPK) and phosphatidylinositol-3 kinase (PI3K) signaling pathways, IGF-1 that is bound to IGF-1R may play a role in promotion of mitosis and cell migration, and inhibition of apoptosis [47]. Additionally, IGF-1 can stimulate tumor angiogenesis by increasing vascular endothelial growth factor (VEGF) levels [48]. IGFBP-3 may inhibit the activity of IGF-1 through competitive binding to IGF-1, because IGF-1 has a higher affinity for IGFBP-3 than for its receptors. Moreover, IGFBP-3 regulates the biological functions of IGFs, by means of controlling their transport from circulation into tissues, modulating their metabolism and clearance, and establishing their specific location on tissues and cells [49]. Although no correlation was observed between serum IGFBP-3 levels and RCC [45,50], high expression of IGFBP-3 was found in clear cell RCC tissue, and high grade (Fuhrman grades 3 and 4) clear cell RCC showed higher IGFBP-3 staining intensity than low grade clear cell RCC [51]. Considering the close link between IGFs and RCC, potential therapeutics targeting IGFs might be promising for the treatment of RCC.

\section{Inflammation}

As a typical alteration in obesity, both hyperplasia and hypertrophy of adipocytes may lead to tissue hypoxia, and subsequently the induction of a series of proinflammatory cytokines. These cytokines, such as tumor necrosis factor- $\alpha$ (TNF- $\alpha$ ), interleukin-6 (IL-6), IL-8, IL-10, and macrophage inflammatory protein 1 (MIP-1), have been shown to stimulate angiogenesis and promote IR, as well as being pivotal to tumor development.

Under the conditions of MS, elevated levels of reactive oxygen species (ROS) (together with pro-inflammatory cytokines and certain mediators involved in inflammation status, such as NF-kB and cyclooxygenase-2 (COX-2)) are known to affect cell apoptosis, proliferation, and invasion. It has been shown that both IL-6 and IL-10 are strongly expressed in RCC cells and stroma. Further, IL-10 levels were higher in more advanced (pT3) tumors, suggesting that IL-6 and IL-10 may be useful markers associated with the development and progression of RCC [52]. TNF- $\alpha$, another vital cytokine, was found to be positively correlated with IR and waist circumference [53]. Likewise, TNF- $\alpha$ is capable of promoting proliferation and metastasis of RCC cells, and mediating epithelial-mesenchymal transition of RCC via GSK3 $\beta$ [54]. ROS directly affect RCC and induce cell apoptosis via activation of the NF- $\mathrm{kB}$ pathway and downregulation of COX-2 [55].

Considerable interest has been devoted to COX-2, a key enzyme in prostaglandins synthesis, and its contribution to cancer. It has been documented that COX-2 is overexpressed in various cancers, including RCC, in which it was correlated with VEGF expression [56,57]. Additionally, IGF-IR and COX-2 may produce a synergistic effect in the oncogenesis and progression of RCC [58]. Nevertheless, Kankuri et al. reported that COX-2 expression was associated with slow development of 
metastases, and favorable prognosis in metastatic RCC [59]. As the current first-line drug targeting VEGF pathways, sunitinib has been applied in the clinic for the treatment of advanced RCC. It has been reported that Cox-2 inhibition enhanced the activity of sunitinib in human RCC xenografts [60].

\section{Adipokines}

Adiponectin, which is primarily secreted by white adipose tissue, functions as a regulator of glucose and lipid metabolism and energy homeostasis. In addition to overall obesity, central fat distribution is thought to be an independent negative predictor of serum adiponectin [61], and weight loss may increase serum adiponectin levels [62]. Adipose tissue hypoxia may also result in the reduction of adiponectin and further research has shown that hypoxia and TNF- $\alpha$ downregulate the activity of the adiponectin gene promoter [63]. The anti-tumor role of adiponectin has been ascribed in part to its antiinflammatory and anti-proliferative effect, as well as antagonism to IR. It was found that serum adiponectin levels were adversely associated with RCC [64]. Moreover, Pinthus et al. reported that low blood adiponectin levels had a strong correlation with tumor size and metastasis of RCC, and could potentially be used as a biomarker [65]. In vitro experiments have demonstrated that adiponectin can inhibit tumor growth via activating AMP-activated protein kinase (AMPK), thereby downregulating mammalian target of rapamycin (mTOR) pathways [66]. Additionally, as an endogenous inhibitor, adiponectin plays an inhibitory role on tumor angiogenesis [67].

Another important adipocyte-specific protein produced predominantly by white adipose tissue is leptin, which acts centrally to mediate satiety and bodyweight [68]. Uncontrolled energy intake and being overweight take place as a result of abnormal levels and/or function of leptin. Elevated levels of serum leptin and overexpression of leptin receptors are associated with RCC invasion and progression, and activation of the extracellular signal-regulated kinases (ERK1/2) and janus kinase/ signal transducer and activator of transcription 3 (JAK/ STAT3) signaling pathways participates in leptin-mediated proliferation of RCC Caki-2 cells [69-71]. By suppressing apoptosis, promoting cell proliferation and upregulating VEGF via hypoxia-inducible factor- $1 \alpha$ (HIF- $1 \alpha)$ and NF- $k B$, leptin boosts carcinogenesis [72]; HIF-1 $\alpha$ and VEGF are thus involved as crucial factors promoting RCC formation and development.

\section{Peroxisome proliferator- activated receptors (PPARs)}

PPARs belong to the nuclear hormone receptor superfamily and consist of three subtypes: PPAR $\alpha$, PPAR $\beta$, and PPAR $\gamma$. These ligand-activated transcription factors contribute significantly to MS and other diseases. For example, PPAR $\alpha$ can activate fatty acid catabolism and PPAR $\beta$ participates in fatty acid oxidation. With respect to PPARy, it has been shown to improve IR, regulate adipocyte differentiation, and play an important role in inflammation, autoimmune diseases, and cancers. Many experiments delineated a high expression of PPAR $\gamma$ in RCC tissue. PPARy ligands were found to inhibit human RCC cell proliferation by induction of apoptosis and G0/ G1cell cycle arrest [73,74]. Pioglitazone is a highly selective type of PPAR $\gamma$ ligand that serves as an insulin sensitizer and is used to treat patients with type 2 diabetes. The multiple antitumor effects of pioglitazone on RCC in vitro, such as suppression of cell growth, induction of apoptosis and inhibition of VEGF and basic fibroblast growth factor secretion, were reported by Yuan et al. [75]. A recent piece of research indicated that 15-deoxyDelta12,14-prostaglandin J2 (a novel kind of PPAR ligand) exerts cytotoxic effects on RCC cells via activation of c-Jun $\mathrm{N}$ terminal kinase (JNK)/MAPK and Akt pathways, in addition to induction of apoptosis [76]. Furthermore, therapies targeting PPAR $\alpha$ are applied for dyslipidemia, and PPAR $\beta$ agonists may be useful to treat obesity, diabetes, and cardiovascular diseases. All of the above research demonstrates that PPARs are potent therapeutic targets for MS and cancer.

\section{Hypoxia-inducible factors (HIFs)}

More and more evidence has reported the contribution made by HIFs to MS. Hyperplasia and hypertrophy of adipocytes may lead to local hypoxia, which subsequently upregulates HIF expression and augments macrophage infiltration [77]. In cultured adipocytes and preadipocytes, overexpression of HIF-1 $\alpha$ was also detected when the cells were exposed to hypoxia [78]. Hyperglycemia interferes with HIF- $1 \alpha$ stabilization, although the mechanisms are not well-defined. Conversely, unbalanced HIF-1 $\alpha$ signaling impairs $\beta$-cells, causing insufficient insulin secretion and IR [79-82]. A study investigating the effect of HIF-1 $\alpha$ on obesity and diabetes found the HIF- $1 \alpha$ knockout mice manifested resistance to weight gain, while ameliorating IR [83]. Venous hypertension stimulates HIF-1 overexpression, and consequent upregulation of VEGF [84]. In an oxygen-deficient environment, activation of the HIF signaling pathway results in lipid accumulation, and downregulates PPAR $\alpha$ expression in a HIF-1-dependent manner [85]. It has been documented that exposure to hypoxia increases IL-6, leptin and monocyte migration inhibitory factor expression of adipocytes in vitro, however it was also shown to decrease adiponectin expression [78].

The role of hypoxia in RCC carcinogenesis has been verified. As a response to oxygen deficiency, HIFs not only participate in energy homeostasis, such as glucose and lipid metabolism, but also have effects on tumor development, by means of regulating the cell cycle, apoptosis, 
and angiogenesis. HIF- $1 \alpha$ was found to increase intratumor microvessel density in xenografts, as well as being overexpressed in RCC [86]. Additionally, high expression of HIF- $1 \alpha$ seems to indicate a poor prognosis [87]. In a retrospective study examining the prognostic prediction of HIF- $1 \alpha$ in metastatic RCC patients, researchers found that patients with high HIF- $1 \alpha$ expression had significantly worse survival than those with low expression (median survival: 13.5 versus 24.4 months, respectively) [88].

High expression of HIFs in RCC is closely related to inactivation of the von-Hippel-Lindau (VHL) gene. Somatic mutations in this gene are detected in approximately $50 \%$ of sporadic RCC, while VHL hypermethylation is seen in $10 \%$ to $20 \%$ of sporadic RCC [89]. As the VHL gene product, $\mathrm{pVHL}$ is absent owing to the inactivation of VHL, which mimics hypoxia and elicits a constitutive up-regulation of HIF- $1 \alpha$, via NF- $\kappa B$ activation [90]. As a result of HIF-1 $\alpha$ overexpression, several factors involved in carcinogenesis and angiogenesis, such as VEGF, platelet-derived growth factor- $\beta$ (PDGF- $\beta$ ) and TGF- $\beta$, are upregulated. Although more comprehensive research is needed, it is believed that hypoxia acts as a common key factor in both MS and RCC; the significance of further research lies in revealing the mechanisms and developing therapeutic interventions.

\section{Mammalian target of rapamycin (mTOR)}

mTOR, a high molecular weight serine-threonine kinase which belongs to the superfamily of phosphatidylinositol 3-kinase (PI3K)-related kinases, is involved in cell growth, proliferation, autophagy, survival, metabolism, and angiogenesis. Deregulation of the PI3K signaling pathway is a feature of various tumors, and it is estimated to account for up to $30 \%$ of all human cancers [91,92]. MS is able to trigger changes in signals upstream of mTOR, and then regulate the processes of downstream pathways via mTOR, including protein synthesis, lipid metabolism, and mitochondrial metabolism. Insulin and IGF-1 may promote cell anabolism through mTOR. If glucose regulation is impaired, abnormality of some growth factors pathways, for example, IGF-1, will result in improper activation of mTOR and/or inactivation of mTOR inhibitors, causing various pathologies, including cancer. Meanwhile, an imbalance in the mTOR pathway leads to deterioration of IR [93], resulting in a vicious cycle. In the course of inflammation, TNF- $\alpha$ activates IкB kinase- $\beta$ $(\mathrm{IKK} \beta)$, which then inactivates mTOR inhibitors, thereby activating the mTOR pathway [94]. Further, obesity can raise mTOR levels, which is also involved in HIF- $1 \alpha$ translation [95]. Conversely, hypoxia activates mTOR inhibitors via AMPK, leading to blockage of the mTOR pathway [96].

Mutation of the tumor suppressor PTEN and activation of PI3K, both of which are common in many kinds of cancers, mediate hyperactivation of mTOR. In some studies, researchers have detected low PTEN expression, and high expression of PI3K/mTOR, in clear cell RCC [97,98]. Further, high PI3K/mTOR expression seems to be associated with poorer prognosis [99,100]. Given the importance of mTOR for RCC, great progress has been made in targeting mTOR. Everolimus and Temsirolimus have both been approved by the FDA to treat advanced RCC.

\section{Conclusions}

There is abundant evidence regarding the link between MS and RCC, and each component of MS may have a close causal association with RCC. Recent studies have generated exciting findings on the molecular basis of MS-associated RCC. Understanding the molecules involved may provide clues to prevent carcinogenensis in people with MS. Therapeutic interventions targeting these molecular mechanisms likewise manifest a positive perspective for the treatment of RCC. Further, because MS derives at least in part from an unhealthy lifestyle, maintaining a healthy lifestyle may be important in the prophylaxis of many cancers, including RCC.

\section{Competing interests}

The authors declare that they have no competing interests.

\section{Authors' contributions}

GMZ and DWY conceived of the concept and searched references. GMZ and YZ drafted the manuscript. YZ provided the National Science Foundation of China (Grant No. NSFC 81001131). DWY revised the manuscript. All authors read and approved the final manuscript.

\section{Author details}

'Department of Urology, Fudan University Shanghai Cancer Center, No. 270, Dongan Rd, Shanghai 200032, China. ${ }^{2}$ Department of Oncology, Shanghai Medical College, Fudan University, Shanghai, China.

Received: 27 October 2013 Accepted: 20 July 2014

Published: 29 July 2014

\section{References}

1. Ford ES, Li C, Zhao G: Prevalence and correlates of metabolic syndrome based on a harmonious definition among adults in the US. J Diabetes 2010, 2:180-193.

2. Zanchetti A, Hennig M, Baurecht H, Tang R, Cuspidi C, Carugo S, Mancia G: Prevalence and incidence of the metabolic syndrome in the European Lacidipine Study on Atherosclerosis (ELSA) and its relation with carotid intima-media thickness. J Hypertens 2007, 25:2463-2470.

3. Escobedo J, Schargrodsky H, Champagne B, Silva H, Boissonnet CP, Vinueza R, Torres M, Hernandez R, Wilson E: Prevalence of the metabolic syndrome in Latin America and its association with sub-clinical carotid atherosclerosis: the CARMELA cross sectional study. Cardiovasc Diabetol 2009, 8:52.

4. Thomas GN, Ho SY, Janus ED, Lam KS, Hedley AJ, Lam TH, Hong Kong Cardiovascular Risk Factor Prevalence Study Steering C: The US National Cholesterol Education Programme Adult Treatment Panel III (NCEP ATP III) prevalence of the metabolic syndrome in a Chinese population. Diabetes Res Clin Pract 2005, 67:251-257.

5. Reaven GM: Banting lecture 1988. Role of insulin resistance in human disease. Diabetes 1988, 37:1595-1607.

6. Turati F, Talamini R, Pelucchi C, Polesel J, Franceschi S, Crispo A, Izzo F, La Vecchia C, Boffetta P, Montella M: Metabolic syndrome and hepatocellular carcinoma risk. Br J Cancer 2013, 108:222-228. 
7. Wu Q, Chen G, Wu WM, Zhou L, You L, Zhang TP, Zhao YP: Metabolic syndrome components and risk factors for pancreatic adenocarcinoma: a case-control study in China. Digestion 2012, 86:294-301.

8. Lindkvist B, Almquist M, Bjorge T, Stocks T, Borena W, Johansen D, Hallmans G, Engeland A, Nagel G, Jonsson H, Selmer R, Diem G, Haggstrom C, Tretli S, Stattin P, Manjer J: Prospective cohort study of metabolic risk factors and gastric adenocarcinoma risk in the Metabolic Syndrome and Cancer Project (Me-Can). Cancer Causes Control 2013, 24:107-116.

9. Forootan M, Tabatabaeefar M, Yahyaei M, Maghsoodi N: Metabolic syndrome and colorectal cancer: a cross-sectional survey. Asian Pac J Cancer Prev 2012, 13:4999-5002

10. Haggstrom C, Stocks T, Rapp K, Bjorge T, Lindkvist B, Concin H, Engeland A, Manjer J, Ulmer H, Selmer R, Tretli S, Hallmans G, Jonsson H, Stattin P: Metabolic syndrome and risk of bladder cancer: prospective cohort study in the metabolic syndrome and cancer project (Me-Can). Int J Cancer 2011, 128:1890-1898.

11. Hammarsten J, Peeker R: Urological aspects of the metabolic syndrome. Nat Rev Urol 2011, 8:483-494

12. Shou HF, Ni J, Zhu T, Chen JH, Zhang X, Xu XX, Chen L, Yu H: Association between endometrial cancer and metabolic syndrome. Chin J Obstet Gynecol 2010, 45:128-131.

13. Penaranda EK, Shokar N, Ortiz M: Relationship between Metabolic Syndrome and History of Cervical Cancer among a US National Population. ISRN Oncol 2013, 2013:840964.

14. Esposito K, Chiodini P, Capuano A, Bellastella G, Maiorino MI, Rafaniello C, Giugliano D: Metabolic syndrome and postmenopausal breast cancer: systematic review and meta-analysis. Menopause 2013, 12:1301-1309.

15. Esposito K, Chiodini P, Colao A, Lenzi A, Giugliano D: Metabolic syndrome and risk of cancer: a systematic review and meta-analysis. Diabetes Care 2012, 35:2402-2411.

16. Buschemeyer WC 3rd, Freedland SJ: Obesity and prostate cancer: epidemiology and clinical implications. Eur Urol 2007, 52:331-343.

17. Mondul AM, Clipp SL, Helzlsouer KJ, Platz EA: Association between plasma total cholesterol concentration and incident prostate cancer in the CLUE II cohort. Cancer Causes Control 2010, 21:61-68.

18. Shen $Z$, Ye $Y$, Bin $L$, Yin $M$, Yang $X$, Jiang $K$, Wang S: Metabolic syndrome is an important factor for the evolution of prognosis of colorectal cancer: survival, recurrence, and liver metastasis. Am J Surg 2010, 200:59-63.

19. Pasanisi P, Berrino F, De Petris M, Venturelli E, Mastroianni A, Panico S: Metabolic syndrome as a prognostic factor for breast cancer recurrences. Int J Cancer 2006, 119:236-238.

20. Han RF, Sun BC, Yao Z: Kidney cancer. Beijing: People's Medical Publishing House; 2010

21. Chow WH, Gridley G, Fraumeni JF Jr, Jarvholm B: Obesity, hypertension, and the risk of kidney cancer in men. N Engl J Med 2000, 343:1305-1311.

22. Bergstrom A, Hsieh CC, Lindblad P, Lu CM, Cook NR, Wolk A: Obesity and renal cell cancer-a quantitative review. Br J Cancer 2001, 85:984-990.

23. Leiba A, Kark JD, Afek A, Derazne E, Barchana M, Tzur D, Vivante A, Shamiss A: Adolescent obesity and paternal country of origin predict renal cell carcinoma: a cohort study of 1.1 million 16 to 19 -year-old males. J Urol 2013, 189:25-29.

24. Waalkes S, Merseburger AS, Kramer MW, Herrmann TR, Wegener G, Rustemeier J, Hofmann R, Schrader M, Kuczyk MA, Schrader AJ: Obesity is associated with improved survival in patients with organ-confined clear-cell kidney cancer. Cancer Causes Control 2010, 21:1905-1910.

25. Rogde AJ, Gudbrandsdottir G, Hjelle KM, Sand KE, Bostad L, Beisland C: Obesity is associated with an improved cancer-specific survival, but an increased rate of postoperative complications after surgery for renal cell carcinoma. Scand J Urol Nephrol 2012, 46:348-357.

26. Zhu Y, Wang HK, Zhang HL, Yao XD, Zhang SL, Dai B, Shen YJ, Liu XH, Zhou LP, Ye DW: Visceral obesity and risk of high grade disease in clinical t1a renal cell carcinoma. J Urol 2013, 189:447-453.

27. Steffens S, Grunwald V, Ringe Kl, Seidel C, Eggers H, Schrader M, Wacker F, Kuczyk MA, Schrader AJ: Does obesity influence the prognosis of metastatic renal cell carcinoma in patients treated with vascular endothelial growth factor-targeted therapy? Oncologist 2011, 16:1565-1571.

28. Colt JS, Schwartz K, Graubard BI, Davis F, Ruterbusch J, DiGaetano R, Purdue M, Rothman N, Wacholder S, Chow WH: Hypertension and risk of renal cell carcinoma among white and black Americans. Epidemiology 2011, 22:797-804.
29. Wang G, Hou J, Ma L, Xie J, Yin J, Xu D, Chang W, Tan X, Su T, Zhang H, Cao G: Risk factor for clear cell renal cell carcinoma in Chinese population: a case-control study. Cancer Epidemiol 2012, 36:177-182.

30. Grossman E, Messerli FH, Goldbourt U: Does diuretic therapy increase the risk of renal cell carcinoma? Am J Cardiol 1999, 83:1090-1093.

31. Corrao G, Scotti L, Bagnardi V, Sega R: Hypertension, antihypertensive therapy and renal-cell cancer: a meta-analysis. Curr Drug Saf 2007, 2:125-133.

32. Lindblad P, Chow WH, Chan J, Bergstrom A, Wolk A, Gridley G, McLaughlin JK, Nyren O, Adami HO: The role of diabetes mellitus in the aetiology of renal cell cancer. Diabetologia 1999, 42:107-112.

33. Joh HK, Willett WC, Cho E: Type 2 diabetes and the risk of renal cell cancer in women. Diabetes Care 2011, 34:1552-1556.

34. Li M, Liu J, Hu WL, Jia CH, Li HY, Wen ZH, Zou ZP, Bai XC, Luo SQ: Effect of metformin on apoptosis of renal cell carcinoma cells in vitro and its mechanisms. Nan Fang Yi Ke Da Xue Xue Bao 2011, 31:1504-1508.

35. Liu J, Li M, Song B, Jia C, Zhang L, Bai X, Hu W: Metformin inhibits renal cell carcinoma in vitro and in vivo xenograft. Urol Oncol 2013, 31:264-270.

36. Wulaningsih W, Garmo H, Holmberg L, Hammar N, Jungner I, Walldius G, Van Hemelrijck M: Serum Lipids and the Risk of Gastrointestinal Malignancies in the Swedish AMORIS Study. J Cancer Epidemiol 2012, 2012:792034.

37. Inoue M, Noda M, Kurahashi N, Iwasaki M, Sasazuki S, Iso H, Tsugane S: Impact of metabolic factors on subsequent cancer risk: results from a large-scale population-based cohort study in Japan. Eur J Cancer Prev 2009, 18:240-247.

38. Magura L, Blanchard R, Hope B, Beal JR, Schwartz GG, Sahmoun AE: Hypercholesterolemia and prostate cancer: a hospital-based case-control study. Cancer Causes Control 2008, 19:1259-1266.

39. Pothiwala P, Jain SK, Yaturu S: Metabolic syndrome and cancer. Metab Syndr Relat Disord 2009, 7:279-288.

40. Kucharska-Newton AM, Rosamond WD, Mink PJ, Alberg AJ, Shahar E, Folsom AR: HDL-cholesterol and incidence of breast cancer in the ARIC cohort study. Ann Epidemiol 2008, 18:671-677.

41. Lim U, Gayles T, Katki HA, Stolzenberg-Solomon R, Weinstein SJ, Pietinen P Taylor PR, Virtamo J, Albanes D: Serum high-density lipoprotein cholesterol and risk of non-hodgkin lymphoma. Cancer Res 2007, 67:5569-5574.

42. Van Hemelrijck M, Garmo H, Hammar N, Jungner I, Walldius G, Lambe M, Holmberg L: The interplay between lipid profiles, glucose, BMI and risk of kidney cancer in the Swedish AMORIS study. Int J Cancer 2012, 130:2118-2128.

43. Ahn J, Lim U, Weinstein SJ, Schatzkin A, Hayes RB, Virtamo J, Albanes D: Prediagnostic total and high-density lipoprotein cholesterol and risk of cancer. Cancer Epidemiol Biomarkers Prev 2009, 18:2814-2821.

44. Horiguchi A, Ito K, Sumitomo M, Kimura F, Asano T, Hayakawa M: Decreased serum adiponectin levels in patients with metastatic renal cell carcinoma. Jpn J Clin Oncol 2008, 38:106-111.

45. Rasmuson T, Grankvist K, Jacobsen J, Olsson T, Ljungberg B: Serum insulinlike growth factor- 1 is an independent predictor of prognosis in patients with renal cell carcinoma. Acta Oncol 2004, 43:744-748.

46. Rosendahl AH, Forsberg G: IGF-I and IGFBP-3 augment transforming growth factor-beta actions in human renal carcinoma cells. Kidney Int 2006, 70:1584-1590.

47. Ibrahim YH, Yee D: Insulin-like growth factor-I and cancer risk. Growth Horm IGF Res 2004, 14:261-269.

48. Hoeben A, Landuyt B, Highley MS, Wildiers H, Van Oosterom AT, De Bruijn EA: Vascular endothelial growth factor and angiogenesis. Pharmacol Rev 2004, 56:549-580.

49. Li Y, Zhong YB, Lu L, Chen C, Duan CM: Research progress of insulin-like growth factor binding protein-3. Periodical of Ocean University of China 2011, 41:41-47.

50. Major JM, Pollak MN, Snyder K, Virtamo J, Albanes D: Insulin-like growth factors and risk of kidney cancer in men. Br J Cancer 2010, 103:132-135.

51. Chuang ST, Patton KT, Schafernak KT, Papavero V, Lin F, Baxter RC, Teh BT, Yang XJ: Over expression of insulin-like growth factor binding protein 3 in clear cell renal cell carcinoma. J Urol 2008, 179:445-449.

52. Cardillo MR, Ippoliti F: Interleukin-6, interleukin-10 and heat shock protein-90 expression in renal epithelial neoplasias and surrounding normal-appearing renal parenchyma. Int J Immunopathol Pharmacol 2007, 20:37-46. 
53. Zinman B, Hanley AJ, Harris SB, Kwan J, Fantus IG: Circulating tumor necrosis factor-alpha concentrations in a native Canadian population with high rates of type 2 diabetes mellitus. J Clin Endocrinol Metab 1999, 84:272-278.

54. Ho MY, Tang SJ, Chuang MJ, Cha TL, Li JY, Sun GH, Sun KH: TNF-alpha induces epithelial-mesenchymal transition of renal cell carcinoma cells via a GSK3beta-dependent mechanism. Mol Cancer Res 2012, 10:1109-1119.

55. Ambrose M, Ryan A, O'Sullivan GC, Dunne C, Barry OP: Induction of apoptosis in renal cell carcinoma by reactive oxygen species: involvement of extracellular signal-regulated kinase 1/2, p38delta/ gamma, cyclooxygenase-2 down-regulation, and translocation of apoptosis-inducing factor. Mol Pharmacol 2006, 69:1879-1890.

56. Li J, Wang G, Chu Y, Rong R, Zhu T: The clinical application of COX-2 inhibitors may strengthen the sensitivity of renal cell carcinoma to immunotherapy. Med Hypotheses 2008, 71:527-529.

57. Chang BD, Cao LS, Zhou HL: Expression of COX-2 and VEGF and their correlation with angiogenesis in human clear cell renal cell carcinoma. Zhonghua Zhong Liu Za Zhi 2009, 31:687-690.

58. Sun H, Wang H, Qin WJ, Yang B, Wang SC, Jian BL: Expression of IGF-IR and COX-2 in renal cell carcinoma and their relationship with cell proliferation. Xi Bao Yu Fen Zi Mian Yi Xue Za Zhi 2009, 25:348-350.

59. Kankuri-Tammilehto MK, Soderstrom KO, Pelliniemi TT, Vahlberg T, Pyrhonen SO, Salminen EK: Prognostic evaluation of COX-2 expression in renal cell carcinoma. Anticancer Res 2010, 30:3023-3030.

60. Wang X, Zhang L, O'Neill A, Bahamon B, Alsop DC, Mier JW, Goldberg SN, Signoretti S, Atkins MB, Wood CG, Bhatt RS: Cox-2 inhibition enhances the activity of sunitinib in human renal cell carcinoma xenografts. $\mathrm{Br} J \mathrm{Cancer}$ 2013, 108:319-326.

61. Gavrila A, Chan JL, Yiannakouris N, Kontogianni M, Miller LC, Orlova C, Mantzoros CS: Serum adiponectin levels are inversely associated with overall and central fat distribution but are not directly regulated by acute fasting or leptin administration in humans: cross-sectional and interventional studies. J Clin Endocrinol Metab 2003, 88:4823-4831.

62. Coppola A, Marfella R, Coppola L, Tagliamonte E, Fontana D, Liguori E, Cirillo T, Cafiero M, Natale S, Astarita C: Effect of weight loss on coronary circulation and adiponectin levels in obese women. Int J Cardiol 2009, 134:414-416.

63. Ukkola O, Santaniemi M: Adiponectin: a link between excess adiposity and associated comorbidities? J Mol Med (Berl) 2002, 80:696-702.

64. Spyridopoulos TN, Petridou ET, Skalkidou A, Dessypris N, Chrousos GP, Mantzoros CS: Low adiponectin levels are associated with renal cell carcinoma: a case-control study. Int J Cancer 2007, 120:1573-1578.

65. Pinthus JH, Kleinmann N, Tisdale B, Chatterjee S, Lu JP, Gillis A, Hamlet T, Singh G, Farrokhyar F, Kapoor A: Lower plasma adiponectin levels are associated with larger tumor size and metastasis in clear-cell carcinoma of the kidney. Eur Urol 2008, 54:866-873.

66. Sugiyama M, Takahashi H, Hosono K, Endo H, Kato S, Yoneda K, Nozaki Y Fujita K, Yoneda M, Wada K, Nakagama H, Nakajima A: Adiponectin inhibits colorectal cancer cell growth through the AMPK/mTOR pathway. Int J Oncol 2009, 34:339-344.

67. Brakenhielm E, Veitonmaki N, Cao R, Kihara S, Matsuzawa Y, Zhivotovsky B, Funahashi T, Cao Y: Adiponectin-induced antiangiogenesis and antitumor activity involve caspase-mediated endothelial cell apoptosis. Proc Natl Acad Sci U S A 2004, 101:2476-2481.

68. Margetic S, Gazzola C, Pegg GG, Hill RA: Leptin: a review of its peripheral actions and interactions. Int J Obes Relat Metab Disord 2002, 26:1407-1433.

69. Horiguchi A, Sumitomo M, Asakuma J, Asano T, Zheng R, Asano T, Nanus DM, Hayakawa M: Increased serum leptin levels and over expression of leptin receptors are associated with the invasion and progression of renal cell carcinoma. J Urol 2006, 176:1631-1635.

70. Horiguchi A, Sumitomo M, Asakuma J, Asano T, Zheng R, Asano T, Nanus DM, Hayakawa M: Leptin promotes invasiveness of murine renal cancer cells via extracellular signal-regulated kinases and rho dependent pathway. $J$ Urol 2006, 176:1636-1641.

71. Li L, Gao Y, Zhang LL, He DL: Concomitant activation of the JAK/STAT3 and ERK1/2 signaling is involved in leptin-mediated proliferation of renal cell carcinoma Caki-2 cells. Cancer Biol Ther 2008, 7:1787-1792.

72. Gonzalez-Perez RR, Xu Y, Guo S, Watters A, Zhou W, Leibovich SJ: Leptin upregulates VEGF in breast cancer via canonic and non-canonical signalling pathways and NFkappaB/HIF-1alpha activation. Cell Signal 2010, 22:1350-1362

73. Inoue K, Kawahito Y, Tsubouchi Y, Kohno M, Yoshimura R, Yoshikawa T, Sano $\mathrm{H}$ : Expression of peroxisome proliferator-activated receptor gamma in renal cell carcinoma and growth inhibition by its agonists. Biochem Biophys Res Commun 2001, 287:727-732.

74. Yang FG, Zhang ZW, Xin DQ, Shi CJ, Wu JP, Guo YL, Guan YF: Peroxisome proliferator-activated receptor gamma ligands induce cell cycle arrest and apoptosis in human renal carcinoma cell lines. Acta Pharmacol Sin 2005, 26:753-761.

75. Yuan J, Takahashi A, Masumori N, Uchida K, Hisasue S, Kitamura H, Itoh N, Tsukamoto T: Ligands for peroxisome proliferator-activated receptor gamma have potent antitumor effect against human renal cell carcinoma. Urology 2005, 65:594-599.

76. Fujita M, Tohji C, Honda Y, Yamamoto Y, Nakamura T, Yagami T, Yamamori M, Okamura N: Cytotoxicity of 15-deoxy-Delta $(12,14)$-prostaglandin J (2) through PPARgamma-independent pathway and the involvement of the JNK and Akt pathway in renal cell carcinoma. Int J Med Sci 2012, 9:555-566.

77. Pasarica M, Sereda OR, Redman LM, Albarado DC, Hymel DT, Roan LE, Rood JC, Burk DH, Smith SR: Reduced adipose tissue oxygenation in human obesity: evidence for rarefaction, macrophage chemotaxis, and inflammation without an angiogenic response. Diabetes 2009, 58:718-725

78. Wang B, Wood IS, Trayhurn P: Dysregulation of the expression and secretion of inflammation-related adipokines by hypoxia in human adipocytes. Pflugers Arch 2007, 455:479-492.

79. Gunton JE, Kulkarni RN, Yim S, Okada T, Hawthorne WJ, Tseng YH, Roberson RS, Ricordi C, O'Connell PJ, Gonzalez FJ, Kahn CR: Loss of ARNT/HIF1 beta mediates altered gene expression and pancreatic-islet dysfunction in human type 2 diabetes. Cell 2005, 122:337-349.

80. Cheng K, Ho K, Stokes R, Scott C, Lau SM, Hawthorne WJ, O'Connell PJ, Loudovaris T, Kay TW, Kulkarni RN, Okada T, Wang XL, Yim SH, Shah Y, Grey ST, Biankin AV, Kench JG, Laybutt DR, Gonzalez FJ, Kahn CR, Gunton JE: Hypoxia-inducible factor-1alpha regulates beta cell function in mouse and human islets. J Clin Invest 2010, 120:2171-2183.

81. Ochiai D, Goda N, Hishiki T, Kanai M, Senoo-Matsuda N, Soga T, Johnson RS, Yoshimura Y, Suematsu M: Disruption of HIF-1alpha in hepatocytes impairs glucose metabolism in diet-induced obesity mice. Biochem Biophys Res Commun 2011, 415:445-449.

82. Yu J, Shi L, Wang H, Bilan PJ, Yao Z, Samaan MC, He Q, Klip A, Niu W: Conditioned medium from hypoxia-treated adipocytes renders muscle cells insulin resistant. Eur J Cell Biol 2011, 90:1000-1015.

83. Jiang C, Qu A, Matsubara T, Chanturiya T, Jou W, Gavrilova O, Shah YM, Gonzalez FJ: Disruption of hypoxia-inducible factor 1 in adipocytes improves insulin sensitivity and decreases adiposity in high-fat diet-fed mice. Diabetes 2011, 60:2484-2495.

84. Zhu Y, Lawton MT, Du R, Shwe Y, Chen Y, Shen F, Young WL, Yang GY: Expression of hypoxia-inducible factor- 1 and vascular endothelial growth factor in response to venous hypertension. Neurosurgery 2006, 59:687-696. discussion 687-696.

85. Narravula S, Colgan SP: Hypoxia-inducible factor 1-mediated inhibition of peroxisome proliferator-activated receptor alpha expression during hypoxia. J Immunol 2001, 166:7543-7548.

86. Kondo Y, Hamada J, Kobayashi C, Nakamura R, Suzuki Y, Kimata R, Nishimura T, Kitagawa T, Kunimoto M, Imura N, Hara S: Over expression of hypoxiainducible factor-1alpha in renal and bladder cancer cells increases tumorigenic potency. J Urol 2005, 173:1762-1766.

87. Lidgren A, Hedberg Y, Grankvist K, Rasmuson T, Vasko J, Ljungberg B: The expression of hypoxia-inducible factor 1alpha is a favorable independent prognostic factor in renal cell carcinoma. Clin Cancer Res 2005, 11:1129-1135

88. Klatte T, Seligson DB, Riggs SB, Leppert JT, Berkman MK, Kleid MD, Yu H, Kabbinavar FF, Pantuck AJ, Belldegrun AS: Hypoxia-inducible factor 1 alpha in clear cell renal cell carcinoma. Clin Cancer Res 2007, 13:7388-7393.

89. Kim WY, Kaelin WG: Role of VHL gene mutation in human cancer. J Clin Oncol 2004, 22:4991-5004

90. An J, Rettig MB: Mechanism of von Hippel-Lindau protein-mediated suppression of nuclear factor kappa B activity. Mol Cell Biol 2005, 25:7546-7556.

91. Samuels Y, Wang Z, Bardelli A, Silliman N, Ptak J, Szabo S, Yan H, Gazdar A, Powell SM, Riggins GJ, Willson JK, Markowitz S, Kinzler KW, Vogelstein B, 
Velculescu VE: High frequency of mutations of the PIK3CA gene in human cancers. Science 2004, 304:554.

92. Nicholson KM, Anderson NG: The protein kinase B/Akt signalling pathway in human malignancy. Cell Signal 2002, 14:381-395.

93. Lamming DW, Ye L, Katajisto P, Goncalves MD, Saitoh M, Stevens DM Davis JG, Salmon AB, Richardson A, Ahima RS, Guertin DA, Sabatini DM, Baur JA: Rapamycin-induced insulin resistance is mediated by mTORC2 loss and uncoupled from longevity. Science 2012, 335:1638-1643

94. Lee DF, Kuo HP, Chen CT, Hsu JM, Chou CK, Wei Y, Sun HL, Li LY, Ping B, Huang WC, He X, Hung JY, Lai CC, Ding Q, Su JL, Yang JY, Sahin AA, Hortobagyi GN, Tsai FJ, Tsai CH, Hung MC: IKK beta suppression of TSC1 links inflammation and tumor angiogenesis via the mTOR pathway. Cell 2007, 130:440-455.

95. Hudson CC, Liu M, Chiang GG, Otterness DM, Loomis DC, Kaper F, Giaccia AJ Abraham RT: Regulation of hypoxia-inducible factor 1alpha expression and function by the mammalian target of rapamycin. Mol Cell Biol 2002, 22:7004-7014.

96. Liu L, Cash TP, Jones RG, Keith B, Thompson CB, Simon MC: Hypoxia-induced energy stress regulates mRNA translation and cell growth. Mol Cell 2006, 21:521-531.

97. Cancer Genome Atlas Research Network: Comprehensive molecular characterization of clear cell renal cell carcinoma. Nature 2013, 499:43-49.

98. Cheng T, Zhang JG, Cheng YH, Gao ZW, Ren XQ: Relationship between PTEN and Livin expression and malignancy of renal cell carcinomas. Asian Pac J Cancer Prev 2012, 13:2681-2685.

99. Merseburger AS, Hennenlotter J, Kuehs U, Simon P, Kruck S, Koch E, Stenzl A, Kuczyk MA: Activation of PI3K is associated with reduced survival in renal cell carcinoma. Urol Int 2008, 80:372-377.

100. Elfiky AA, Aziz SA, Conrad PJ, Siddiqui S, Hackl W, Maira M, Robert CL, Kluger HM: Characterization and targeting of phosphatidylinositol-3 kinase (PI3K) and mammalian target of rapamycin (mTOR) in renal cell cancer. J Transl Med 2011, 9:133.

doi:10.1186/1477-7819-12-236

Cite this article as: Zhang et al:: Metabolic syndrome and renal cell carcinoma. World Journal of Surgical Oncology 2014 12:236.

\section{Submit your next manuscript to BioMed Central and take full advantage of:}

- Convenient online submission

- Thorough peer review

- No space constraints or color figure charges

- Immediate publication on acceptance

- Inclusion in PubMed, CAS, Scopus and Google Scholar

- Research which is freely available for redistribution 